DOI: https://doi.org/10.34069/AI/2021.48.12.4

How to Cite:

Kostikova, I., Chastnyk, O., Ptushka, A., Yazlovytska, O., \& Dovzhenko, O. (2021). Digital technology implementation in students' proficiency development for english listening. Amazonia Investiga, 10(48), 34-42. https://doi.org/10.34069/AI/2021.48.12.4

\title{
Digital technology implementation in students' proficiency development for english listening
}

\section{Впровадження цифрових технологій у розвиток навичок аудіювання англійської Мови}

Received: November 9, 2021

Accepted: December 23, 2021
Written by:

Kostikova Ilona ${ }^{8}$

https://orcid.org/0000-0001-5894-4846

Chastnyk Oleksandr ${ }^{9}$

https://orcid.org/0000-0001-5188-5097

Ptushka Anastasiia ${ }^{10}$

https://orcid.org/0000-0003-3177-5370

Yazlovytska Olena ${ }^{11}$

https://orcid.org/0000-0001-7326-1234

Dovzhenko Olga ${ }^{12}$

https://orcid.org/0000-0002-0761-9901

\begin{abstract}
The article proposes a research that shows digital technology for developing students' proficiency in listening comprehension using the offered Internet resources, the created learning site and well-known on-line apps as it is aimed. The research methods has been used to demonstrate the finding of the paper: the questionnaires in order to analyze students' attitude to learning with sites; tests for getting students' progress in developing listening competence; Student's t-test as a statistical method to estimate the results of pedagogical experiment. In general, 88 universities students took part in this research during 2020-2021. As a conclusion we can state that listening competence is less ready to progress. The present research opens the perspectives for further researches of developing English listening proficiency on-line.
\end{abstract}

\begin{abstract}
Анотація
У статті пропонується дослідження, яке показує впровадження цифрових технологій для розвитку у студентів навичок розуміння аудіювання з використанням запропонованих Інтернет-ресурсів, створеного навчального сайту та відомих онлайн-додатків за своїм призначенням. Для демонстрації результатів дослідження використано наступні методи: анкетування 3 метою аналізу ставлення студентів до навчання за допомогою сайтів; тести для визначення досягнення успіхів студентів у розвитку компетенції 3 аудіювання; статистичні методи (критерій Стьюдента t-test), які допомогли оцінити результати педагогічного експерименту. Загалом у цьому дослідженні протягом 20202021 років взяли участь 88 студентів різних університетів. Як висновок можна констатувати, що компетенція 3 аудіювання складно піддається прогресу. Дане дослідження відкриває перспективи для подальших досліджень розвитку аудіювання англійською мовою он-лайн.
\end{abstract}

\footnotetext{
${ }^{8}$ Dr. Sc, PhD in Education, Full Professor, Department of Theory and Practice of the English Language, H. S. Skovoroda Kharkiv National Pedagogical University, Kharkiv, Ukraine.

${ }^{9} \mathrm{PhD}$ in Art Criticism, Associate Professor, Department of Foreign Languages \# 1, Yaroslav Mudryi National Law University, Kharkiv, Ukraine.

${ }^{10} \mathrm{PhD}$ in Philology, Associate Professor, Department of Foreign Language Teaching Methods and Practice, V. N. Karazin Kharkiv National University, Kharkiv, Ukraine.

${ }^{11} \mathrm{PhD}$ in Philology, Associate Professor, Department of Foreign Language Teaching Methods and Practice, V. N. Karazin Kharkiv National University, Kharkiv, Ukraine.

${ }^{12} \mathrm{PhD}$ in Pedagogy, Associate Professor, Department for Philosophic and Psychological Anthropology, H. S. Skovoroda Kharkiv National Pedagogical University, Kharkiv, Ukraine.
} 


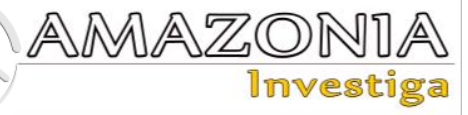

Keywords: digital, technology, listening, comprehension, on-line, English.

\section{Introduction}

Nowadays the use of digital technologies for educational purposes is becoming vitally crucial, as the modern world development is gradually making the Internet an everyday reality for students and teachers, and information and communication technologies create a new global on-line environment. And it is especially relevant during the pandemic. In this environment the future generation should not only communicate, but also build professional and personal relationships, define their interests and present themselves. And their personal well-being and professional success will depend on how well they succeed. That is why in recent years the great importance is attached to the digital technologies in education systems.

And these are digital teaching technologies that allow academic staff to individualize and differentiate teaching and learning; to exercise testing, students' self-control; visualize educational information; model and simulate the studied processes and phenomena; to create the ability to make the optimal decision in various situations; to develop a certain kind of thinking; to strengthen motivation to learn; to develop a culture of cognitive activity, etc. The use of educational Internet technologies in the classroom expands the teachers' capabilities in the selection of both learning materials and forms of educational work, makes classes bright and interesting, informative and emotionally rich.

Speaking about teaching foreign languages, it is significant to underline that means of digital technologies have special possibilities in the development of speech competence in English, since some researchers state as a fact that a person remembers $20 \%$ of heard information, $40 \%$ of seen information, $60 \%$ of seen and heard information, $80 \%$ of those that he/she has seen, heard and done independently. And such technologies allow teachers to combine all forms. So, digital technologies success students' level in foreign language listening proficiency.

Being the underlying basis of any communication, listening behaviour, auditory receiving, attending, perceiving and interpreting information, considered as a part of a student's learning activity, requires particular attention to be paid and special research to be conducted. It is the analysis that serves to help to solve the
Ключові слова: цифровий, технологія, аудіювання, розуміння, он-лайн, англійська мова.

problem, since, above all, it focuses on the mechanisms of perception and processing of language and speech.

No doubt, listening is an internally inactive form of speech activity. The active nature of listening is explained by the fact that its basis is built on the processes of partial speech modeling. Listening is mediated by the speaking of another person, sense perception is not planned, analytic and synthetic operations unfold at the input of listening, the product of which is the conclusion of the mind.

The wide applying Internet technologies allows teachers to ensure development of speech listening that is necessary for teaching foreign communication skills and that is practically absent in students' ordinary life in their native country.

The experience of listening to authentic texts through Internet resources is beneficial to the development and skills of auditing and makes up the lack of a natural foreign language environment. In addition, authentic documents are widely applied to bring students closer to the future use of the language of public communication. Speaking about Internet technologies for developing listening skills, it is worth focusing on some of the on-line resources that are freely available and can be effectively implemented in University English language teaching, in particular, listening comprehension teaching. Let alone that their usage helps to simulate the conditions of real communication, to create an atmosphere of authentic communication situation.

Texts from Internet resource for listening comprehension preserve all the characteristics of a natural speech production, but methodically processed (i.e. specially composed and simplified, readable slowly and accompanied by the full printed text of the message, so called 'script'), prepared for the pedagogical process, are equated with authentic ones.

Preserving the authenticity of teaching materials in a foreign language teaching is a general trend of modern methodology, which is applied on numerous educational Internet sites, where not only texts, but also text materials (a kind of 
educational and methodological complex for the teacher: audio text, script text, tasks for each of the paragraphs of the text (exercises for understanding the content and fixing the lexical units on the topic, creative tasks, and answers) and separate complexes for the study) can be found. It is also worth noting that usually the format of such complexes allows teachers to use the texts not only for the classroom work, but when students are doing their homework as well. Moreover, they can be useful for students' selflearning.

In Section "Literature Review" the scholars' papers about Internet technologies, listening comprehension are analyzed, the purpose of the article is defined. In Section "Methodology" the general research methods as theoretical, empirical, statistical ones are described as well as the research procedure. In Section "Results and Discussion" the main Internet resources and podcasts for usage are analyzed, students' prerequisites to on-line learning English are shown; as well as the authors' on-line course "English Fastpass" is offered; the carried pedagogical experiment is described too. In Section "Conclusions" the basic research statement is grounded and the perspectives for further researches are proposed.

\section{Literature Review}

Internet technologies for educational purposes, including foreign language teaching and communicative skills development have been researched in different aspects by a number of scholars. So, cloud-based learning was studied by M. Kayali, N.Satar, M.Mukhtar (Kayali, Satar, \& Mukhtar, 2016), J. Wang (Wang, 2017), M. S. I. A. Abdullahi, N. Salleh, A. A. Alwan (Abdullahi, Salleh, \& Alwan, 2018), M. Arood, M.Aljallad, N.Baioumy (Arood, Aljallad, \& Baioumy, 2020), S. Okai-Ugbaje, K. Ardzejewska, A. Imran, A. Yakubu, M. Yakubu (Okai-Ugbaje et al, 2020), N. Samyan, P.O. St Flour (Samyan, \& St Flour, 2021); using Interactive Whiteboard was considered by E. Aflalo, L. Zana, T. Huri (Aflalo, Zana, \& Huri, 2018), certain educational services as well as websites were investigated by H.Shim, S.Lee (Shim, \& Lee, 2018), J. M. Macancela (Macancela, 2019).

Some aspects of listening comprehension have been investigated by many scholars. Most scientists researched psychological as X. Chen (Chen, 2020), linguistic as N. K. Karimvand (Karimvand, 2011), D. Renukadevi (Renukadevi, 2014), social as K. L. Geeslin,
A. Y. Long (Geeslin, \& Long, 2014) nature of the phenomenon of listening comprehension. Its basic features were considerably described by A. P. Gilakjani, M. R. Ahmadi (Gilakjani, Ahmadi, 2011), A.P. Gilakjani, N. B. Sabouri (Gilakjani, \& Sabouri, 2016a), (Gilakjani, \& Sabouri, 2016b).

Although, as we can see, the analysis of listening comprehension is not a novel problem for researchers, however, the listening comprehension progress using the offered Internet resources, the created learning site and on-line apps in due to the advance all different language skills was not researched.

So, the purpose of the article is to research the use of digital technologies as the offered Internet resources, the created learning site and wellknown on-line apps to the students' listening competence. The tasks are: 1) to describe Internet resources used in the research; 2) to find out students' prerequisites to on-line learning; 3) to create and offer authors' on-line course for students; 4) to check the students' progress in listening competence.

\section{Methodology}

88 university students from 3 different Ukrainian Universities where the authors teach as H. S. Skovoroda Kharkiv National Pedagogical University, V. N. Karazin Kharkiv National University, Yaroslav Mudryi National Law University took part in the research. The second and third year students learn English as general University subject twice a week during one academic year 2020-2021.

So, the group included 88 students (average age being 20 years old) who belonged to the similar occupational environment (non-linguistic faculties). It would be reasonable to mention their high motivation and dedication determined by the fact that their ultimate goal providing them with the opportunity to participate in various international student programmes as well as live and work independently in an English-speaking country or study on courses taught in English (Alte, 2002).

The following research methods were used:

- theoretical ones such as analysis, synthesis of bibliography in psycholinguistics, psychology, linguistics, pedagogy. Their aim was to distinguish some linguistic listening processes, some psychological and social skills, to characterize comprehension, 


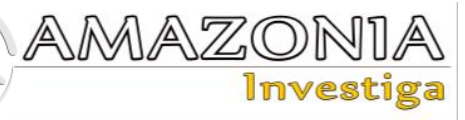

to describe approaches and principles of teaching listening, to interpret listening skill, to formulate conclusions;

- empirical ones such as questionnaires in order to analyse students' attitude to learning sites; pedagogical experiment to compare the results of developing listening comprehension skills using digital technologies;

- $\quad$ statistical ones such as Student's t-test where t-distribution discover the null hypothesis, which were used to evaluate the results of the experiment.

Results and Discussion

Many Internet resources give students the possibility for listening comprehension. Thus, the Internet resource English Central (www.englishcentral.com), which is widely used in our teaching practice, provides students the opportunity to listen the authentic English language. The undeniable advantage of this resource is that listeners can independently choose both the subject of the texts and their level complexity. The program allows, if necessary, to accompany the audio track with subtitles, which is especially relevant at the initial stage of language learning.

Another on-line resource, we can recommend, www.ted.com is world famous. The value of using this resource is that it provides the ability to listen the authentic language in situations close to real communication. The ability to select audio texts increases students' motivation and promotes more effective information assimilation. The difficulty of listening in real communication is in many cases related to peculiarities of a speaker's pronunciation, the timbre of his/her voice, possible language defects, and dialectal characteristics. The available resource provides a wide range of audio texts that demonstrate modern English in all its diversity.

The practice has shown that it is very convenient to use materials from the Listening section of the website www.esl-lab.com (Randall's ESL Cyber Listening). It offers audio texts of different language proficiency levels. What is more, the texts are of a monological and dialogical nature and of various topics, so not only the teacher can always choose an audio text corresponding to the topic studied in the classroom, but also this website may be applied for teaching students of different specialties. In addition, there is a set of methodically developed exercises for each audio text.
They are: keywords are given, a pre-listening exercise, a listening task that excludes passive listening, usually a multiple choice task. Posttext exercises aimed at developing speaking, reading and writing skills, exercises on reinforcement of vocabulary. It is important that the audio texts are performed by adults and children, as it should be remembered that the more the learner will listen to different native speakers (men, women, and children), the easier it is to adapt to the individual style of speech. If the student has difficulties in completing the assignment, it is possible to open the text script of the audio material and read it.

Another listening exercise is to listen to the audio version and fill in the text with the missing words. In addition, this section offers and voiced videos containing additional information on the topic audio materials. Such work with audio material helps to work out the mechanisms of listening: speech hearing, memory, probabilistic forecasting.

In accordance with the work program of the discipline, we choose among the variety audio materials and recommend to students such audio texts as "Daily Schedule", "Weekly Activities", "College Life", "Spending Money", "Restaurants". It is highly convenient to work in this format with the topic "Telephoning", since the exercises offered by the Internet resources we use correlate with the teaching materials that we master on this topic during classroom sessions.

So, at the link www.esllab.com/tel1.htm you will find interactive exercises on this topic: listening to phone numbers and choosing the correct answer, listening to situational dialogues and choosing an answer, listening to speech clichés, sentences on this topic and making an online recording of the listened. In addition to educational Internet resources, the authors actively use the following news sites that unite informative and educational functions (as our students should, on the one hand, improve their English proficiency, and on the other hand, keep abreast of the latest events): The BBC World Service (http://www.bbc.co.uk/worldservice), which provides an opportunity not only to read, but also to listen to news, in many languages. What is more, they offer a large section for English learners - LEARNING ENGLISH. There are a lot of videos, listening and reading texts here.

ABC News (http://www.abcnews.go.com/index. html) provides video guides to its audio publications. CNN World News 
(http://cnn.com/WORLD) also provides information in multiple languages and there is a possibility to call audio and video accompaniment. Breaking News English (https://breakingnewsenglish.com/2008/200809shaving-0.html). Each news item of the resource has exercises to develop listening, reading and writing skills.

An effective way to develop students' listening skills is to use podcasts, which are audio files in the style of radio and television programs on the Internet, we can advise:

http://www.eltpodcast.com; http://www.bbc.co.uk/podcasts/series/tae; http://learnenglish.britishcouncil.org/en/element ary-podcasts. A positive factor in using podcasts is the ability to download them to users' personal digital media. It allows students to listen to them at a convenient time. It was important for us to research students' attitude to on-line sites for learning English and developing listening skills as well.

So, to find out students' prerequisites to on-line learning the questionnaires were used; and 88 university students took part in the survey. We asked university students about their attitude to on-line learning, so, at the figures the students' age, (see figure 1), course type (see figure 2), course content (see figure 3), convenient format (see figure 4), convenient time arrangement (figure 5) are represented.

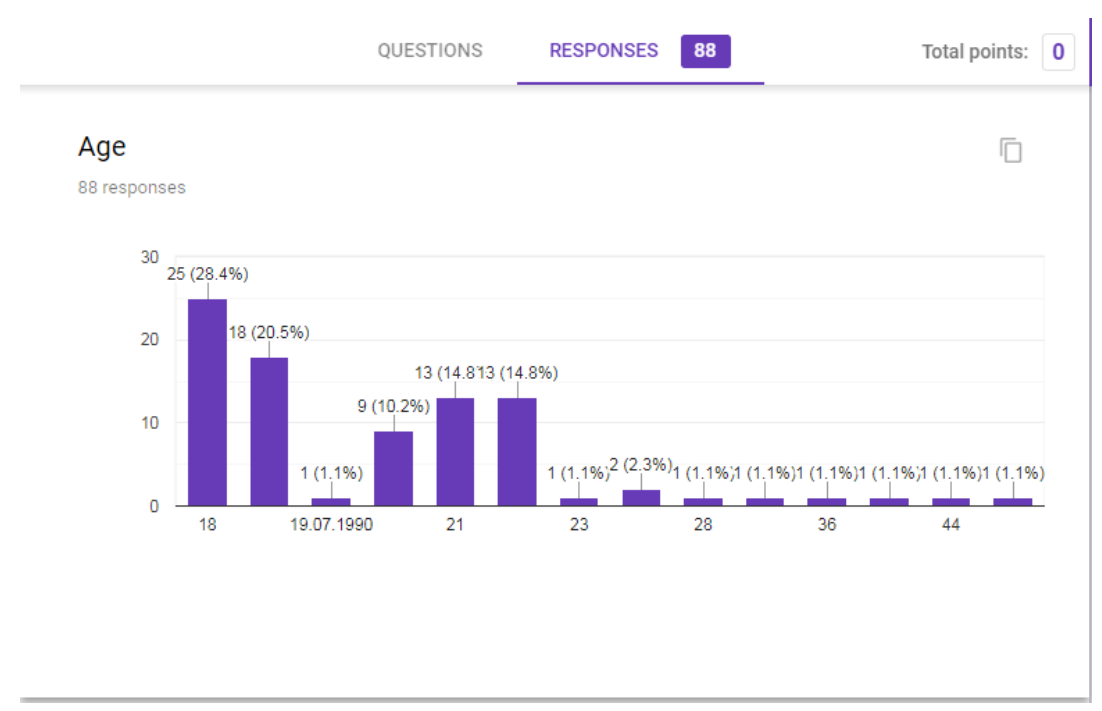

Figure 1. Students' Age.

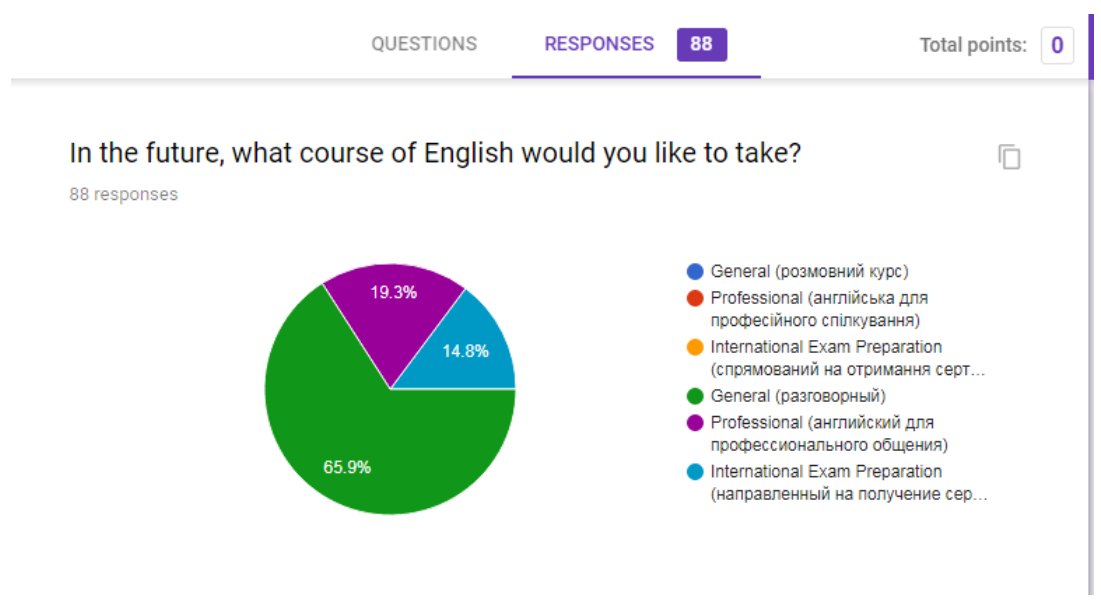

Figure 2. Students' Wishes about the Course Type. 


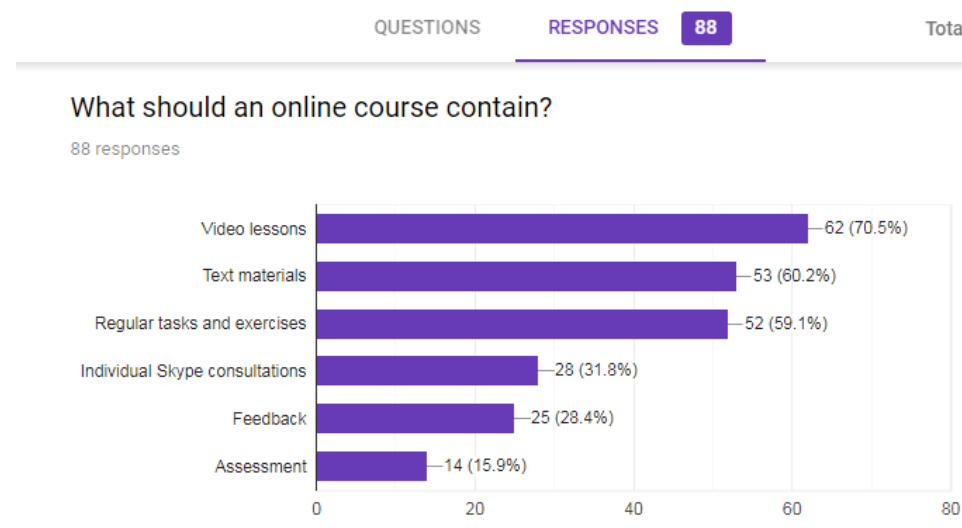

Figure 3. Students' Wishes about the Course Content.

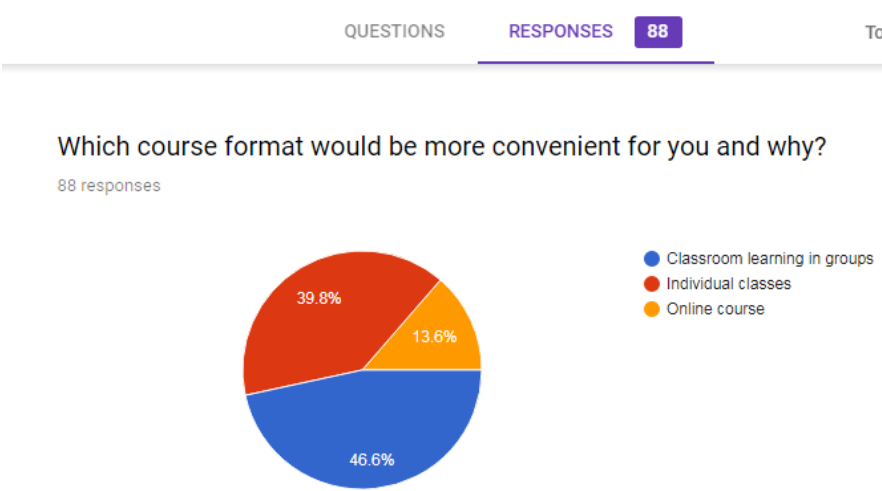

Figure 4. Convenient Format for Students.

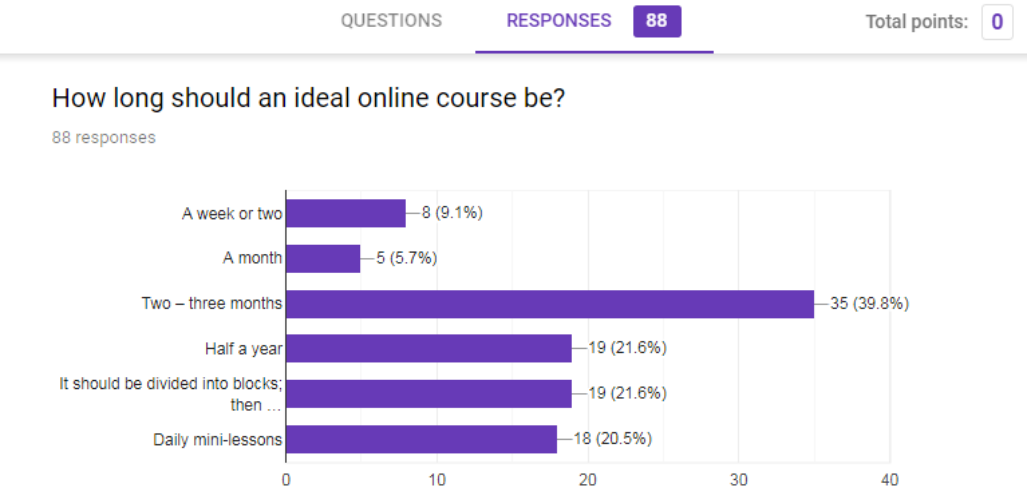

Figure 5. Convenient Time Arrangement for Students.

Due to students' wishes the authors' on-line course was created and offered in 2020-2021, it is called "English Fastpass", http://www.englishfastpass.com. So, "English Fastpass" site was launched for students as the optional, supplementary, additional on-line course. All learning materials on the site are presented in respect to modern requirements for teaching foreign languages and trends of continuing language education. The goals and objectives of the course are determined taking into account the real possibilities and needs of 
students in using a foreign language in various areas of communication, including social, academic and professional.

The students are given the opportunity to identify the level of their English, as well as a large number of covered free test materials, where students practice various types of speech activity, as well as monitor the prepared-note to the final certification. It allows graduates to develop all competences, combining on-line learning.

"English Fastpass" determines the content and test forms at various stages of learning, which are consistent with the stated goals and objectives and ensure both management of students' learning activities in the course of studying and reinforcement of their learning. It is very important, from our point of view, that listening comprehension is learned along with other competencies. It helps to develop listening skills better.

The on-line course includes learning materials for self-study (on-line video lessons, exercises, tests and quizlet cards, YouTube channel), as well as Live Classes, webinars, speaking intensives and telegram chat. These course parts not only provide techniques and strategies for learning, improve knowledge of the English language, but also help to develop different competences and the listening competence as well.

The on-line course helps to understand the learning secrets of the English language, it helps to understand some life hacks how to quickly and effectively cope with tasks. Interactive instruction tasks and exercises provide the opportunity to work out necessary listening skills, as well as repeat the information provided in the video tutorials.

The components of the course are as follows: Video lessons; Interactive exercises / simulators; Tests with the possibility of passing on-line; Modules of the Quizlet mobile application; Webinar; On-line consultation. The potential benefits of current on-line course content over print learning materials are: authentic listening materials with the possibility of constant resources updating; multimedia representation, which is important for the development listening skills and listening comprehension; using creative interactive assignments, including web projects, web quests, digital storytelling that help to develop listening comprehension.

The research was grounded with the use of offered Internet resources, created "English Fastpass" site, on-line e-learning tools and means for students such as Google Classroom, Google Meet, Zoom, Moodle. As well as the use of Quizlet, the use of on-line sound, video (Safranj, 2015), (Yükseli, Kömür, 2017), the use of animation of the authentic target language (Mindari, Sriemulyaningsih, \& Joewono, 2019), the use of multimedia apps (Zhen, 2016), (Pangaribuan, Sinaga, \& Sipayung, 2017). So, it helps students to develop listening comprehension with visual effects, create English speaking surroundings (Kostikova et al, 2019a), (Kostikova et al, 2019b).

The pedagogical experiment was carried out in above mentioned Universities in 2020-2021 with 88 students. As it is known, the skills in a foreign language usually divide into four proper competences: Speaking, Listening, Writing, and Reading. So, teaching listening comprehension is challenging and demanding, but is this competence actually least of all language skills subjected to improvement?

During one academic year we gave students different tests at the beginning of the experiment. It helped us to identify their competences levels. At the experiment ending we gave the students tests too. Then we compared the average scores in competences. The analysis in statistics (Student's t-test) is shown as M $\pm \mathrm{SD} / \mathrm{SEM}$. The distribution as normal was established, the proposed t-test was chosen describing result differentiation as set at $\mathrm{P} \leq 0.05$.

As for competences results: as for Speaking it was 4.1; as for Writing it was 2.5; as for Reading it was 3.2; as for Listening it was 2.6. So, the Overall Performance was 3.1, it shown the progress from 2.5 to 4.1 , we can explain that the null hypothesis is noteworthy, it proved the statistical significance of the results. But we were interested in Listening competence most of all. So, the detailed results in Listening are in table 1 (see table 1). 
Table 1.

The Detailed Results Before and After the Experiment.

\begin{tabular}{llllll}
\hline \multirow{2}{*}{$\begin{array}{l}\text { Level in } \\
\text { competence }\end{array}$} & Before the Experiment & After the Experiment & Growth & $\mathbf{t}$ & $\mathbf{p}$ \\
\cline { 2 - 5 } Listening & Mean \pm SD & Mean \pm SD & 2.6 & 3.1 & $\leq 0.01$ \\
\hline
\end{tabular}

All the tables, images and figures belong to the article authors.

\section{Conclusions}

Digital technologies allow us to combine different practices, textual and visual materials, graphics, videos, language and music, to create on-line real environment, on-line communication. They provide active activities for further students' listening comprehension, flexibility and variation of learning exercises and tests, actualize cognitive activity and develop critical and creative thinking, expand acquisition possibilities, comprehension and representation, allow to create on-line communicative situations, and, finally, in general, make interactive lessons more interesting and attractive. The experiment has confirmed, skills in listening have not developed well in due to other linguistic skills. That opens the perspectives for further researches for developing English language proficiency guided by using Internet resources, sites and on-line learning apps.

\section{Bibliographic references}

Abdullahi, M.S.I.A., Salleh, N., \& Alwan, A.A. (2018). Cloud-based learning system for improving students' programming skills and self-efficacy. Journal of Information and Communication Technology, 17(4), 629-651. Retrieved from http://www.jict.uum.edu.my/images/vol17no 4oct2018/629-651-jict6.pdf

Aflalo, E., Zana, L., \& Huri, T. (2018). The interactive whiteboard in primary school science and interaction. Interactive Learning Environments, 26(4), 525-538. Retrieved from

https://doi.org/10.1080/10494820.2017.1367 695

Alte (2002) The ALTE Can Do Project. Retrieved from http://www.cambridgeenglish.org/images/28 906-alte-can-do-document.pdf

Arood, M., Aljallad, M., \& Baioumy, N. (2020). The Effectiveness of a Cloud-Based Learning Program in Developing Reflective thinking Skills in Islamic Education among Students in UAE. International Journal of Education and Practice, 8, 158-173. Retrieved from DOI: 10.18488/journal.61.2020.81.158.173.
Chen, X. (2020). Psychological Process of English Learners in Listening Comprehension. Revista Argentina de Clínica Psicológica, XXIX(2), 710-716. Retrieved from DOI: 10.24205/03276716.2020.300

Geeslin, K. L., \& Long, A. Y. (2014). Sociolinguistics and Second Language Acquisition. Learning to Use Language in Context. eBook ISBN 9780203117835. New York: Routledge. Retrieved from https://doi.org/10.4324/9780203117835

Gilakjani, A. P., \& Ahmadi, M. R. (2011). A Study of Factors Affecting EFL Learners' English Listening Comprehension and the Strategies for Improvement. Journal of Language Teaching and Research, 2(5), 977-988. Retrieved from DOI: 10.4304/jltr.2.5.977-988

Gilakjani, A. P., \& Sabouri, N. B. (2016a). Learners' Listening Comprehension Difficulties in English Language Learning: A Literature Review. English Language Teaching, 9(6), 123-133. Retrieved from http://dx.doi.org/10.5539/elt.v9n6p123

Gilakjani, A. P., \& Sabouri, N. B. (2016b). The Significance of Listening Comprehension in English Language Teaching. Theory and Practice in Language Studies, 6(8), 1670-1677. Retrieved from http://dx.doi.org/10.17507/tpls.0608.22

Karimvand, N.K. (2011). Psycholinguistic Perspectives on Comprehension in SLA. Journal of Language Teaching and Research, 2(6), 1268-1273. Retrieved from DOI: 10.4304/JLTR.2.6.1268-1273

Kayali, M., Satar, N., \& Mukhtar, M. (2016). Adoption of Cloud Based E-Learning: a Systematic Literature Review of Adoption Factors and Theories. Journal of Engineering and Applied Sciences, 11(8), 1839-1845. Retrieved from DOI: 10.36478/jeasci.2016.1839.1845

Kostikova, I., Holubnycha, L., Shchokina, T., Soroka, N., Budianska, V., \& Marykivska, H. (2019a). A role-playing game as a means of effective professional English teaching. Amazonia Investiga, 8(24), 414-425. Retrieved

from 
https://amazoniainvestiga.info/index.php/am azonia/article/view/1001/927

Kostikova, I., Miasoiedova, S., Razumenko, T., Chernenko, A., \& Pochuieva, O. (2019b). Teaching English speaking for FCE: using Facebook as a tool of instructional practice. Amazonia Investiga, 8(22), 719-727. Retrieved from https://amazoniainvestiga.info/index.php/am azonia/article/view/825/773

Macancela, J. M. (2019). Websites as support tools for learning the English language. Journal of Science and Research: Revista Ciencia E Investigacion, 4(2), 13-20. Retrieved from DOI 10.5281/zenodo. 3240647

Mindari, R., Sriemulyaningsih, M.J. \& Joewono, A. (2019). Young Learners' Responses on the Use of Animation in an English Class. Magister Scientiae, 46, 274-285. Retrieved from https://doi.org/10.33508/mgs.v2i46.2232.

Okai-Ugbaje, S., Ardzejewska, K., Imran, A., Yakubu, A., \& Yakubu, M. (2020). Cloudbased m-learning: A pedagogical tool to manage infrastructural limitations and enhance learning. International Journal of Education and Development using Information and Communication Technology, 16(2), 48-67. Retrieved from https://files.eric.ed.gov/fulltext/EJ1268798.p df

Pangaribuan, T., Sinaga, A., \& Sipayung, K. T. (2017). The Effectiveness of Multimedia Application on Students Listening Comprehension. English Language Teaching, 10(12), 212-218. Retrieved from http://doi.org/10.5539/elt.v10n12p212

Renukadevi, D. (2014). The Role of Listening in Language Acquisition; the Challenges \& Strategies in Teaching Listening.
International Journal of Education and Information Studies, 4(1), 59-63. Retrieved from

https://www.ripublication.com/ijeisv1n1/ijei sv4n1_13.pdf

Safranj, J. (2015). Advancing listening comprehension through movies. Procedia Social and Behavioral Sciences, 191, 169-173. Retrieved from https://doi.org/10.1016/j.sbspro.2015.04.513

Samyan, N., \& St Flour, P. O. (2021). The impact of cloud computing on e-Learning during COVID-19 pandemic. International Journal of Studies in Education and Science, 2(2), 146-172. Retrieved from https://ijses.net/index.php/ijses/article/view/ 25

Shim, H., \& Lee, S. (2018). Development of educational materials using Prezi as digital storytelling tool. Journal of Theoretical and Applied Information Technology, 96(22), 7491-7499. Retrieved from http://www.jatit.org/volumes/Vol96No22/17 Vo196No22.pdf

Wang, J. (2017). Cloud Computing Technologies in Writing Class: Factors Influencing Students' Learning Experience. Turkish Online Journal of Distance EducationTOJDE, 18(3), 13. Retrieved from https://files.eric.ed.gov/fulltext/EJ1147704.p df

Yükseli, C., \& Kömür, Ș. (2017). Using Online Videos to Improve Speaking Abilities of EFL Learners. European Journal of Education Studies, 3(5), 255-266. Retrieved from https://doi.org/10.5281/zenodo.495750

Zhen, Z. (2016). The Use of Multimedia in English Teaching. US-China Foreign Language, 14(3), 182-189. Retrieved from DOI: $10.17265 / 1539-8080 / 2016.03 .002$ 